\title{
THE IMPORTANCE OF ODOURS IN THE WORKPLACE: A REVIEW
}

\author{
Zuzana Kapustová1, Elena Horská ${ }^{2}$, Jakub Berčík ${ }^{3}$, Johana Paluchová ${ }^{4}$, Lubomír \\ Gurčík 5 \\ $1,3,4$ assistent professor, ${ }^{2,5}$ professor \\ Faculty of Economics and Management, Slovak University of Agriculture in Nitra \\ E-mail: zuzana.lajdova@gmail.com, elena.horska@gmail.com,jakubstudio@gmail.com, \\ johana.paluchova@gmail.com, lubomir.gurcik@uniag.sk
}

\begin{abstract}
The most persistent memory on any space is often its odour, therefore the presence of a pleasant odours results in higher self-efficacy, setting higher goals and employing efficient work strategies in comparison to working in a no-scent condition. Moreover, unpleasant odours might increase stress level and result in a loss of productivity. The paper aims to provide a review of the available literature regarding the influence of odours on the human activities with special reference to essential oils in the workplace and their impact on work performance.
\end{abstract}

Keywords: aromachology, essential oil, odour, olfactory, workplace

JEL classification: $M 31$

LCC code: HF5001-6182

\section{Introduction}

The olfactory sense is very substantial psychologically, as well as physiologically, hence the air we breathe has impact on the efficiency and effectiveness of our thinking (ClementsCroome, 2008). Sarafoleanu et al. (2009) note that the olfactory sense could have unbelievable attributes if we consider its' capacity to modulate human behaviours. Georgescu and Raluca (2012) point out that people are all the time, unconsciously, in contact with odours from the environment, the odours affect emotional behaviour and produce sensations of pleasure or aversion. Sowndhararajan - Kim (2016) report that about 300 active olfactory receptor genes are devoted to detecting thousands of different fragrance molecules through a large family of olfactory receptors of a diverse protein sequence, therefore, the sense of smell plays an important role in the physiological effects of mood, stress as well as working capacity. Nørsgaard - Rasmussen (2013) explain the influential effect of odour via the olfactory bulb that is a part of the brain's limbic system - an area closely associated with memory and feelings so called the "emotional brain".

Olfactory effects on mood, physiology and behaviour are studied by aromachology (term coined by the Sense of Smell Institute in 1982), as noted by Herz (2009). According to Choi Han (2015), Aromachology examines the mutual relationship between fragrance technology and psychology, which stimulates the olfactory circuit in the limbic area of the brain and arouses various emotions and feelings. Morley (2004) defines aromachology as the science of the effect of scent on mood and behaviour or the 'Psychology of Scent' and it represents the next stage of the advancement of aromatherapy into the twenty-first century. However, Herz (2009) explains that aromatherapy is not scientifically supported, however, aromachology research must fulfill the following principles: 1) theory guided goals and clear hypothesis testing, 2) using appropriate experimental methodology for testing of fragrances, 3) sufficient and representative subject populations and appropriate contrasting control groups are used, 4) 
appropriate statistical methods are used for analyzing data and 5) the results have been vetted by scientific peers and accepted for publication in journals.

The paper aims to provide a review of the available literature regarding the influence of odours on the human activities with special reference to essential oils in the workplace and their impact on work performance. The main reason is the fact that the influence of scent on consumer behaviour has been investigated in the majority of scientific papers, however, the impact of scent on employee's behaviour has not been investigated to such an extent.

\section{Material and Methods}

Recently published international literature dealing with the selected topic has been examined from the various scientific databases. In order to fulfil the main aim, the comparative method is used for comparing the researchers' opinions on the chosen topic and for explaining the aromachology effects of pleasant odours such as inhalation of essential oils in the workplace. The paper is structured as follows: Section 3 (Results) presents description of benefits of scented offices and also negative consequences of uses of scent to individuals are discussed. This is followed by a description of employees' opinion on scented offices and the application of electroencephalography (EEG), which can measure the response of the human brain to scent stimulus, is explained. Finally, the consequences of inhaling the aromas from essential oils are determined. The conclusion is provided in the Section 4.

\section{Results}

Clements-Croome (2013) states that the physical environment can improve one's work, but on the other hand an unsatisfactory environment can hinder work output. Pleasant fragrances refer to one aspect of the physical environment that can positively affect individual's emotions (Max, 2002). Sowndhararajan - Kim (2016) explain that electrophysiological studies have revealed that various fragrances affected spontaneous brain activities and cognitive functions. Additionally, the most persistent memory on any space is often its odour, thus odours can have impact on cognitive processes that affect creative task performance, as well as personal memories and moods (Clements-Croome, 2008). Unpleasant odours increase the heart rate and that, in turn, might increase stress level and result in a loss of productivity, as mentioned by Welch (1996) (in Saha, 2016). Herz (2002) reports that working in the presence of a pleasant odours results in higher self-efficacy, setting higher goals and employing efficient work strategies in comparison to working in a no-scent condition. Zoladz - Raudenbush (2005) also believe that pleasant odours may lead to cognitive, social, psychological and physiological performance improvement. Research done by Baron (1990) confirmed that participants who were exposed to pleasant scents, set higher goals on a clerical coding task, were more likely to adopt an efficient strategy for performing this task, set higher monetary goals and made more concessions during face-to-face negotiations with an accomplice.

However, Bradford - Desrochers (2009) identify apart from positive also negative consequences of uses of scent to individuals. The benefits include: 1) Engagement in an experience that may not otherwise occur; 2) Improvement in mood; 3) Improvement in sense of well-being and efficiency. On the other hand, the following detriments are considered: 1) Influence to engage in a behaviour that would not otherwise be considered and 2) Influence to change an attitude that would not otherwise occur detriments. Spangenberg et al. (2005) emphasize the significance of a fit between scent and components of the environment in which it is used. 
Summary of benefits of scented offices is shown in Figure 1. Figure 2 presents the survey results on employees' opinion on scented offices.

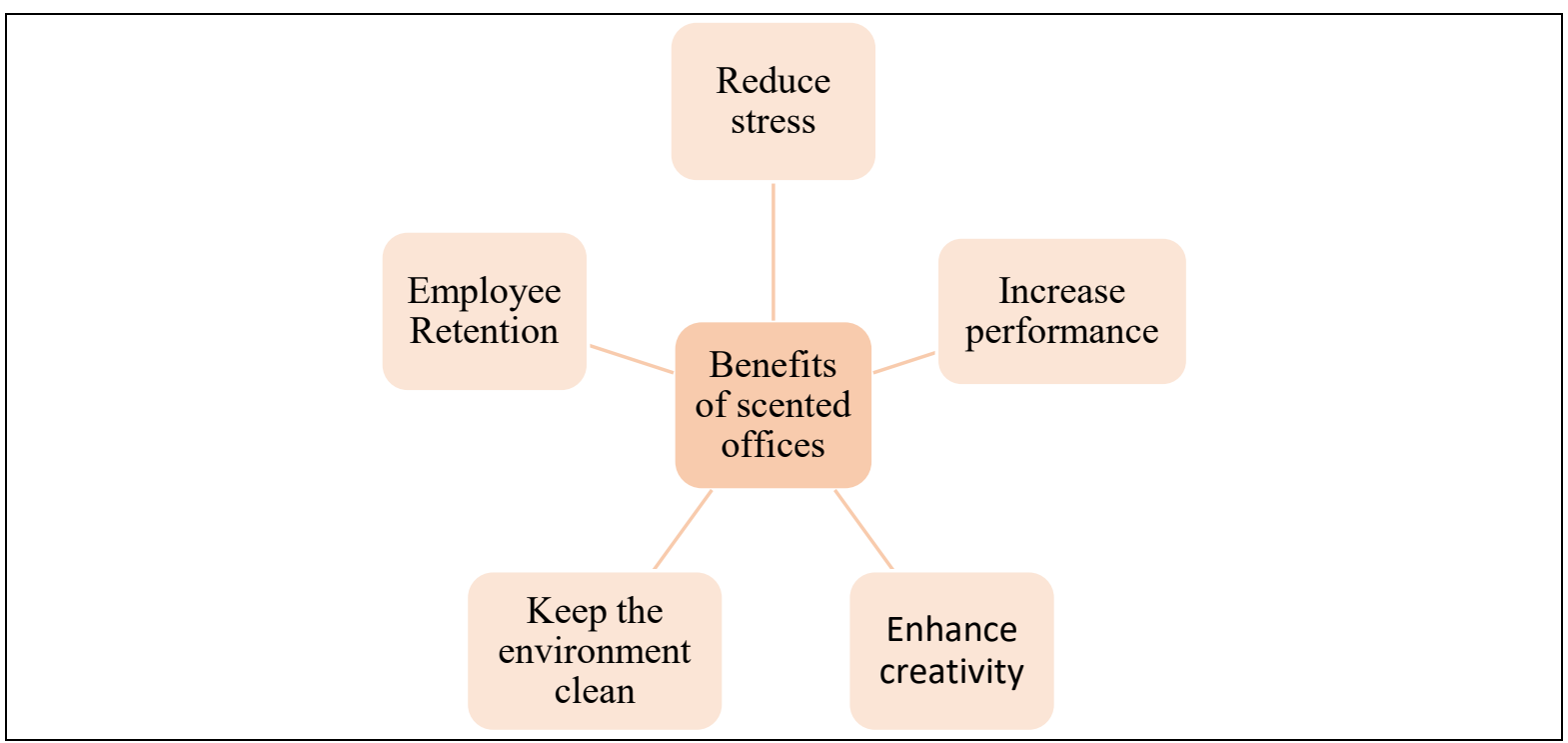

\section{Figure 1: Benefits of Scented Offices}

Source: https://www.reedpacificmedia.com/benefits-of-scent-on-workplace-productivity/; own proceedings

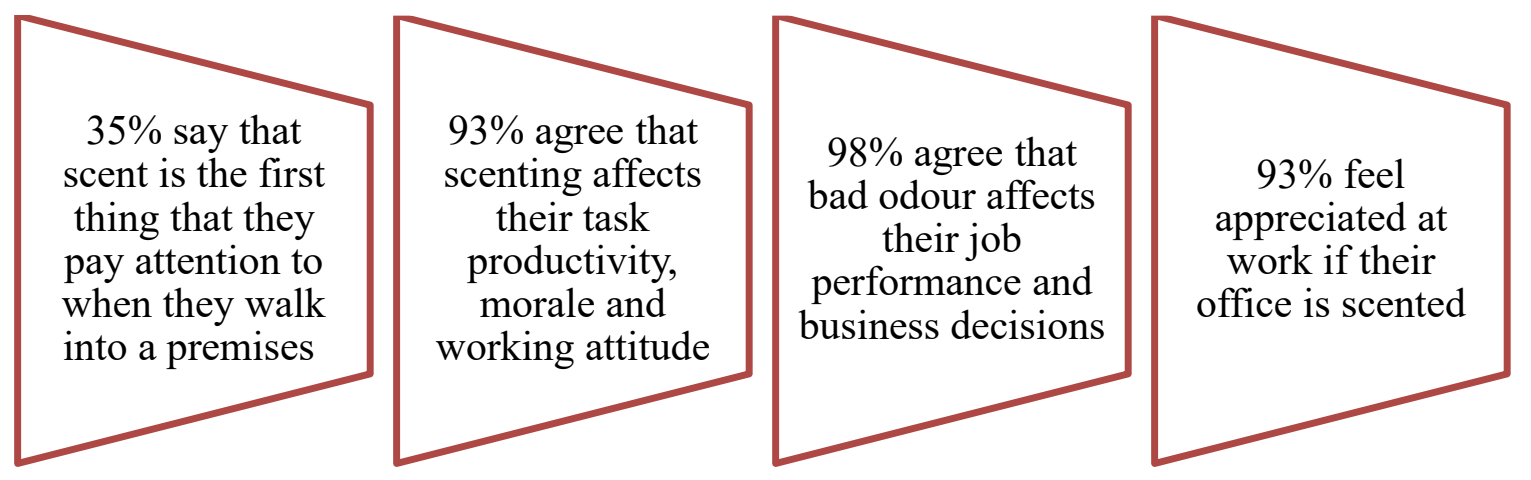

Figure 2: Employees' opinion on scented offices*

Source: https://www.slideshare.net/rentokil-initial-malaysia/initial-premium-scenting-final; own proceedings

Note: *Findings based on a survey with a sample of 40 office executives, age between 19-50 years old

\section{Electroencephalography (EEG)}

Henkin - Levy (2001) state that pleasant odours are more appreciated in the left hemisphere, while unpleasant odours are more appreciated in the right hemisphere. Recent studies have involved the use of electroencephalography (EEG) for measuring the response of the human brain to scent stimulus (Sieow et al., 2013). Casson et al. (2018) explain that EEG is based upon placing metal electrodes on the scalp which measure the small electrical potentials that arise outside of the head due to neuronal action within the brain. Hongratanaworakit (2004) reports that EEG measurements show brain wave responses expressed in brain wave amplitude and frequency. Additionally, aromas produce cortical brain wave activity responses involving alpha, beta, delta, and theta waves. The characteristics of the different types of brain waves are shown in Table 1. 
Table 1: Brain waves

\begin{tabular}{|c|c|c|}
\hline Delta & $\begin{array}{c}\text { Frequency range: } \\
0-4 \mathrm{~Hz}\end{array}$ & $\begin{array}{c}\text { Referred to as a "slow wave" and } \\
\text { represents a state of deep dreamless sleep }\end{array}$ \\
\hline Theta & $\begin{array}{c}\text { Frequency range: } \\
4-8 \mathrm{~Hz}\end{array}$ & $\begin{array}{c}\text { Referred to as a "slow wave" and is } \\
\text { associated with a state of deep relaxation } \\
\text { and meditation, enhanced creativity, } \\
\text { stress relief, light sleep and dreaming. }\end{array}$ \\
\hline Alpha & $\begin{array}{c}\text { Frequency range: } \\
8-12 \mathrm{~Hz}\end{array}$ & $\begin{array}{c}\text { Associated with contemplation, } \\
\text { visualization, problem solving and } \\
\text { accessing deeper levels of creativity }\end{array}$ \\
\hline Beta & $\begin{array}{c}\text { Frequency range } \\
12-40 \mathrm{~Hz}\end{array}$ & $\begin{array}{c}\text { Associated with a } \\
\text { heightened state of alertness and focused } \\
\text { concentration }\end{array}$ \\
\hline
\end{tabular}

Source: Hema - Revathi (2012)

Considering the effects of odour on EEG activity, several studies have revealed an increase of alpha or theta rhythms during the presentation of odour (Masago et al., 2000). The study, based on EEG analysis, found significant alpha and theta wave changes resulting from inhalation of combined lavender and bergamot oil aromas (Lee, 2016). A study conducted by Lorig Schwartz (1988) revealed that aromas such as eucalyptus, lavender, spiced apple were associated with different alpha and theta wave distributions, especially spiced apple odour was the most effective in stimulating alpha activity (relaxing effect of the odour). Another EEG analysis showed that rose oil and sandalwood are better aromas for reducing stress levels in comparison to lavender and lemongrass (Hema -Revathi, 2012). EEG activity was assessed by Diego et al. (1998) who revealed that participants in a lavender-scented environment showed increased beta power, suggesting increased drowsiness. On the other hand, the rosemary aroma caused decreased frontal alpha and beta power, suggesting increased alertness.

\section{Essential oils in the workplace - the recent findings}

Sachin et al. (2016) define that essential oils are odorous, volatile and secondary metabolites produced by diverse group of plants. Essential oils are believed to produce reliable and predictable effects on psychological state when inhaled (Sanderson - Ruddle, 1992). Dąbrowska (2017) says that these oils are called essential because they are considered to represent the quintessential essence of odour and flavour, moreover aromatherapy and aromachology benefit from essential oil biological and sensory properties. Furthermore, the aromas of essential oils can modulate mood and cognitive performance (Moss et al., 2008).

Behavioural studies have explained the consequences of essential oils and fragrances on basic and higher cognitive functions, such as alertness and attention, learning and memory, or problem solving (Baser - Buchbauer, 2016). Tomi et al. (2011) also demonstrate that aromas from plant essential oils show mental and physiological effects so called "aromachology" effects. The authors studied aromachology effects of essential oils from two lavenders (Lavandula angustifolia (called "true lavender") and L. hybrida (called "lavandin")) and revealed some relaxing effects such as decrease of "fatigue" feeling by giving aroma of the both lavender essential oils, however only aroma of the lavender oil from L. angustifolia (called "true lavender") caused an increase of human parasympathetic nerve activity. Study by Sakamoto et al. (2005) confirmed that lavender significantly affected work performance (increased concentration levels), however jasmine did not provide such an effect. However, Rottman (1989) found that jasmine odour helped to improve individuals' performance on 
problem-solving tasks and led participants to indicate higher levels of interest and motivation to the task. Ho - Spence (2005) reported that a significant performance enhancement was achieved by the presence of peppermint odour. Raudenbush et al. (2002) also determined that peppermint odour reduced measures of workload, effort, tiredness, frustration and on the other hand increased self-evaluated performance and energy. Study conducted by Manuel et al. (2014) revealed that peppermint scent increases the attention of the participants, however lavender reduces the ability to concentrate and working memory of the participants. Toth (1989) found out that a lemon scent reduced error rate of operators, working in a large Japanese firm, by almost 50 percent and exposure to lavender was associated with almost 80 percent (in Bradford - Desrochers, 2009). According to Kiecolt-Glaser et al. (2008), lemon is a stimulating and activating odour and might make participants feel more alert and energized, might lift mood, increase heart rate, help think more clearly, and perhaps also provoke positive memories and emotions. Another research showed that people in a coffee-scented (vs. no scent) environment perform better on an analytical reasoning task, moreover people expect that being in a coffee-scented environment will increase their performance because they expect it will increase their physiological arousal level (Madzharov et al., 2018). Zoladz - Raudenbush (2005) showed that cinnamon odour improved attentional processes, virtual recognition and working memory, and visual-motor response speed. Keller (2017) defines six scents that can improve productivity and performance of a company: 1) Rosemary for stimulating the mind, improving memory retention, relief of fatigue, headaches and muscular aches and pains and it helps workers concentrate on the task at hand; 2) Lemon relieves tension, anger and anxiety in the workplace and promotes the perception of cleanliness; 3) Lavender for high stress work environments; 4) Cinnamon creates alertness, improves focus and accurate attention to detail; 5) Jasmine offers relief from stress, tension, anxiety and depression; 6) Peppermint promotes concentration and focused thinking.

The results of the study by Sugawara et al. (1998) demonstrated that the inhalation of an essential oil caused a different subjective perception of the fragrance depending on the type of work. For example, inhalation of basil after mental work produced a much more favourable impression than that before work. Later on, the authors added that inhalation of cypress after physical work produced a much more favourable impression than before work, in comparison to orange, which produced an unfavourable impression after physical work when compared with that before work (Sugawara et al., 1999).

\section{Conclusions}

The paper presented recent findings regarding the influence of odours on the human activities with special reference to essential oils inhaled in the workplace and their impact on work performance. Recent studies have confirmed that pleasant odour represents one way to improve productivity at workplace. In addition, pleasant odours may lead to cognitive, social, psychological and physiological performance improvement. On the contrary, the presence of unpleasant odours in the workplace might increase stress level and result in a loss of productivity. Essential oils, for instance rosemary, lemon, lavender, cinnamon, jasmine, peppermint etc., can help boost productivity of employees and their inhalation cause a different aromachology effects on individual's performance. In most cases, the aromas of essential oils affect basic and higher cognitive functions, such as alertness and attention, learning and memory, or problem solving. 


\section{Acknowledgement}

Research has been supported by the research grant APVV-17-0564 "The Use of Consumer Neuroscience and Innovative Research Solutions in Aromachology and its Application in Production, Business and Services.

\section{References}

1. Baser K. - Buchbauer G. (2016): Handbook of Essential Oils: Science, Technology, and Applications. Boca Raton: CRC Press. 1128 p., ISBN 978-1-4665-9046-5

2. Baron R.A. (1990): Environmentally Induced Positive Affect: Its Impact on SelfEfficacy, Task Performance, Negotiation, and Conflict. Journal of Applied Social Psychology. Vol. 20. No. 5. 368-384. p., https://doi.org/10.1111/j.15591816.1990.tb00417.x

3. Bradford K. D. - Desrochers D. M. (2009): The Use of Scents to Influence Consumers: The Sense of Using Scents to Make Cents. [Online]. [Accessed 10 September 2018]. Available at: https://eprints.mdx.ac.uk/7171/1/Desrochers-Scent_revision_Jan_30.pdf

4. Casson A. J. - Abdulaal M. - Dulabh M. - Kohli S. - Krachunov S. - Trimble E. (2018): Electroencephalogram. In: Tamura, T. - Chen, W. (eds). Seamless Healthcare Monitoring. Springer, Cham. 45-81. p., https://doi.org/10.1007/978-3-319-69362-0_2

5. Choi Nak-Eon - Han J. H. (2015): How Flavor Works. The Science of Taste and Aroma. John Wiley and Sons Ltd. 240 p., ISBN 978-1-118-86547-7

6. Clements-Croome D. J. (2008): Work performance, productivity and indoor air. SJWEH Suppl. No. 4. 69-78. p., ISSN 0355-3140

7. Clements-Croome D. (2013): Why does the environment matter? In: Beyond Environmental Comfort. Routledge, 139-160. p., ISBN 9780415453691

8. Dąbrowska J. A. (2017): Known and unknown products from raw materials of plant origin. World Scientific News. Vol. 76. 23-28. p., ISSN 2392-2192

9. Diego M. A. - Jones N. A. - Field T. - Hernandez-Reif M. - Schanberg S. - Kuhn C. - McAdam V - Galamaga R. - Galamaga M. (1998): Aromatherapy positively affects mood, EEG patters of alertness and math computations. International Journal of Neuroscience. Vol. 96. No. 3-4. 217-224. p., ISSN 0020-7454. https://doi.org/10.3109/00207459808986469

10. Georgescu M. - Raluca E. (2012): Considerations on the evolution and importance of the olfactory sense and odorous molecules in human history. Romanian Journal of Rhinology. Vol. 2. No. 8. 225-230. p., ISSN 2069-6523

11. Hema C. R. - Revathi S. (2012): A Preliminary Study on Aromatheraphy as a Stress Buster Using EEG Signal Analysis. Emerging Trends in Engineering Research. 211219. p., ISBN 978-93-82338-32-1

12. Henkin R. I. - Levy, L. M. (2001): Lateralization of brain activation to imagination and smell of odors using functional magnetic resonance imaging (fMRI): left hemispheric location of pleasant and right hemispheric localization of unpleasant odors. Journal of Computer Assisted Tomography. Vol. 25. No. 4. 493-514. p., ISSN: 0363-8715

13. Herz R. S. (2002): Do scents affect people's moods or work performance? Scientific American. [Online]. [Accessed 12 September 2018]. Available at: https://www.scientificamerican.com/article/do-scents-affect-peoples/

14. Herz R. S. (2009): Aromatherapy facts and fictions: A scientific analysis of olfactory effects on mood, physiology and behaviour. International Journal of Neuroscience. Vol. $119 . \quad$ No. $2 . \quad 263-290 . \quad$ p., $\quad$ ISSN 1543-5245. https://doi.org/10.1080/00207450802333953 
15. Ho C. - Spence C. (2005): Olfactory facilitation of dual-task performance. Neuroscience Letters. Vol. 389. No. 1. 35-40. p., ISSN 0304-3940. https://doi.org/10.1016/j.neulet.2005.07.003

16. Hongratanaworakit T. (2004): Physiological effects in aromatherapy. Songklanakarin J. Sci. Technol. Vol. 26. No. 1. 117-125. p., ISSN 0125-3395

17. Kiecolt-Glaser J. K. - Graham J. E. - Malarkey W. B. - Porter K. - Lemeshow S. Glaser R. (2008): Olfactory Influences on Mood and Autonomic, Endocrine, and Immune Function. Psychoneuroendocrinology. Vol. 33. No. 3. 328-339. p., ISSN 0306-4530. doi: 10.1016/j.psyneuen.2007.11.015

18. Keller H. (2017): 6 Scents to Aroma Brand Office Atmosphere \& Increase Productivity. [Online]. [Accessed 20 September 2018]. Available at: /www.airscent.com/6-scents-to-aroma-brand-office-atmosphere-increaseproductivity/

19. Lee I. (2016): Effects of Inhalation of Relaxing Essential Oils on Electroencephalogram Activity. International Journal of New Technology and Research. Vol. 2. No. 5. 37-43. p., ISSN 2454-4116

20. Lorig T. S. - Schwartz G. E. (1988): Brain and odor I. Alteration of human EEG by odor administration. Psychobiology. Vol. 16. 281-289. p., ISSN 0889-6313

21. Madzharov A. - Ye N. - Morrin M. - Block L. (2018): The impact of coffee-like scent on expectations and performance. Journal of Environmental Psychology. Vol. 57. 8386. p., ISSN 0272-4944. https://doi.org/10.1016/j.jenvp.2018.04.001

22. Manuel S. J. - Syazwan M. - Han C. W. - Fazliyana W. N. - Awal M. B. (2014): Peppermint and Lavender Essential Oils: Are They Therapeutic Aromas for Attention and Memory?. The Internet Journal of Alternative Medicine. Vol. 9. No. 1. ISSN: $1540-2584$

23. Masago R. - Matsuda T. - Kikuchi Y. - Miyazaki Y. (2000): Effects of Inhalation of Essential Oils on EEG Activity and Sensory Evaluation. Journal of Physiological Anthropology. Vol. 19. No. 1. 35-42 p., ISSN 1347-5355. https://doi.org/10.2114/jpa.19.35

24. Max U. (2002): Emotional Branding: Playing with the Senses: A Conceptual Approach. 131 p. ISBN: 9783832453299.

25. Morley J. (2004): Aromatherapy: the future. International Journal of Cosmetic Science. Vol. 26. No. 3. 170-170. p. ISSN 1468-2494. https://doi.org/10.1111/j.14672494.2004.00219_08.x

26. Moss M. - Hewitt S. - Moss L. - Wesnes K. (2008): Modulation of cognitive performance and mood by aromas of peppermint and ylang-ylang. International Journal of Neuroscience. Vol. 118. 59-77. p., ISSN 0020-7454. https://doi.org/10.1080/00207450601042094

27. Nørsgaard C. V. - Rasmussen R. S. (2013): A study on olfactory brand enhancement of brand recognition. Master Thesis, Department of marketing, Copenhagen Business School. No. STU: 224.116.

28. Raudenbush B. - Meyer B. - Eppich B. (2002): Effects of odor administration on objective and subjective measures of athletic performance. International Sports Journal. Vol. 6. No. 1. 14-27. p.

29. Reed Pacific Media (n.d.): 5 Reasons Why Scent Will Make Your Workplace More Productive. [Online]. [Accessed 22 September 2018]. Available at: https://www.reedpacificmedia.com/5-reasons-why-scent-will-make-your-workplacemore-productive/ 
30. Rentokil Initial Malaysia (2014): Office Premium Scenting. [Online]. [Accessed 22 September 2018]. Available at: https://www.slideshare.net/rentokil-initialmalaysia/initial-premium-scenting-final

31. Rottman T. R. (1989): The effects of ambient odor on the cognitive performance, mood, and activation, of low and high impulsive individuals in a naturally arousing situation. Doctoral Dissertation. $252 \mathrm{p}$.

32. Sachin A. J. - Bhalerao P. P. - Patil S. J. - Desai B. S. (2016): Essential oils beyond aroma - a review. Current Horticulture. Vol. 4. No. 2. 3-6. p., ISSN 2347-7377

33. Saha S. (2016): A study on impact of workplace design on employee's productivity in selected IT companies in Pune region. International Journal of Business and General Management (IJBGM). Vol. 5. No. 1. 25-38. p., ISSN 2319-2275

34. Sakamoto, R. - Minoura, K. - Usui, A. - Ishizuka,Y. - Kanba, S. (2005): Effectiveness of aroma on work efficiency: Lavender aroma during recesses prevents deterioration of work performance. Chem. Senses. Vol. 30. No. 8. 683-691. p., https://doi.org/10.1093/chemse/bji061

35. Sanderson H. - Ruddle J. (1992): Aromatherapy and Occupational Therapy. British Journal of Occupational Therapy. Vol. 55. No. 8. 310-314. p. ISSN 0308-0226. https://doi.org/10.1177/030802269205500807

36. Sarafoleanu C. - Mella C. - Georgescu M. - Perederco C. (2009): The importance of the olfactory sense in the human behavior and evolution. Journal of Medicine and Life. Vol. 2. No. 2. 196-198. p., ISSN 1844-3117

37. Sieow B. F. - Ser W. - Ho M. W. - Lwin M. O. - Kwok K. (2013): 3D characterization and trend analysis of scents from EEG recordings of repeated scent exposure. 35th Annual International Conference of the IEEE Engineering in Medicine and Biology Society (EMBC). 1330-3. p., ISSN 1094-687X. https://doi.org/10.1109/EMBC.2013.6609754

38. Sowndhararajan K. - Kim S. (2016): Influence of Fragrances on Human Psychophysiological Activity: With Special Reference to Human Electroencephalographic Response. Scientia Pharmaceutica. Vol. 84. No. 4. 724-752. p., https://doi.org/10.3390/scipharm84040724

39. Spangenberg E. R. - Grohmann B. - Sprott, D.E. (2005): It's beginning to smell (and sound) a lot like Christmas: The interactive effects of ambient scent and music in a retail setting. Journal of Business Research. Vol. 58. No. 11. 1583-1589. p., ISSN 0148-2963. https://doi.org/10.1016/j.jbusres.2004.09.005

40. Sugawara Y. - Tomota T. - Tamura K. (1998): Perceived Fragrance of Essential Oils in Relation to Type of Work. Journal of Home Economics of Japan. Vol. 49. No. 12. 1281-1290. p., ISSN 1882-0352

41. Sugawara Y. - Hino Y. - Kawasaki M. - Hara Ch. - Tamura K. - Sugimoto N. Yamanishi Y. - Miyauchi M. - Masujima T. - Aoki T. (1999): Alteration of Perceived Fragrance of Essential Oils in Relation to Type of Work: a Simple Screening Test for Efficacy of Aroma. Chemical Senses, Vol. 24. No. 4. 415-421. p., ISSN 14643553. https://doi.org/10.1093/chemse/24.4.415

42. Tomi K. - Fushiki T. - Murakami H. - Matsumura Y. - Hayashi T. - Yazawa S. (2011): Relationships between Lavender Aroma Component and Aromachology Effect. Acta Horticulturae. 925. 299-306. p., https://doi.org/10.17660/ActaHortic.2011.925.44

43. Toth D. (1989): What's New in Fragrances; To Relax or Stay Alert, New MoodAltering Scents, The New York Times, September 24, page H1.

44. Zoladz P. R. - Raudenbush B. (2005): Cognitive Enhancement through Stimulation of the Chemical Senses. North American Journal of Psychology. Vol. 1. No. 1. 125-140. p., ISSN 1527-7143 